\title{
Povjerljivi izvještaji obavještajnog odjela Generalštaba vojske Kraljevine Jugoslavije o ustaškoj emigraciji (Hrvatskom komitetu) 1937. - 1940.: dokumenti
}

Državni organi Kraljevine Jugoslavije u godinama uoči izbijanja Drugoga svjetskog rata pratili su aktivnosti raznih separatističkih organizacija koje su bile nezadovoljne položajem svojih nacija u Kraljevini. Vrhovni generalštab (Glavni đeneralštab) preko obavještajnog je odjela pratio što se događa među makedonskim, albanskim i hrvatskim emigrantima te je svaka tri mjeseca izvještavao o njihovu djelovanju. Kopije tih izvještaja već se nekoliko desetljeća nalaze pohranjene u Institutu za nacionalnu istoriju u Skopju, u dokumentarnom odjeljenju. U dvojezičnom (albansko-makedonskom) izdanju Makedonskog državnog arhiva (Državen Arhiv na Republika Makedonija) objavljeni su dokumenti koji se odnose na Kosovski komitet. ${ }^{1}$ Zahvaljujući Muzaferu Bislimiju, uredniku toga izdanja, kopije dokumenata koji se odnose na Hrvatski komitet (ustašku organizaciju) u ovom će se radu prezentirati hrvatskoj javnosti. Izvršena je transliteracija s ćirilice na latinicu, ali je tekst prenesen u originalu - na srpskom jeziku, uz sve jezične nepreciznosti i netočnosti koje se u njemu nalaze. Budući da sam bio u posjedu samo onih dijelova teksta koji se odnose na Hrvatski komitet, u priređivanju dokumenata za čitanje pomoglo mi je spomenuto makedonsko izdanje pa sam u većini slučajeva mogao odgonetnuti kada je i tko pisao izvještaje te kome su oni bili namijenjeni.

Dokument $1^{2}$

Kraljevina Jugoslavija

Glavni đeneralštab, obaveštajno odelenje, Str.pov.G, Ob. Br. 1137, 6.7. 1937 g. VOJNOM IZASLANIKU U ARBANIJI

Доверливи извештаи на тајната служба на генералштабот на војската на Кралството СХС -Југославија за Косовскиот комитет (1924-1941) - Документи (ед. Музафер Бислими), Државен архив на Република Македонија, Скопје 2017. / Raporte sekrete ushtarake të Mbretërisë SKS- Jugosllave, për Komitetin e Kosovës (1924-1941) - Dokumente (ed. Muzafer Bislimi), Arkivi Shtetëror i Republikës së Maqedonisë, Shkup 2017.

2 INI, Skopje, Dokumentaciono oddelenie, KXXXVI/7 Br. 740. 
Tromesečni izveštaj o komitetima: MAKEDONSKOM, KOSOVSKOM i HRVATSKOM za mesece IV,V I VI 1937. G

U prilogu pod/1, dostavlja se tromesečni izveštaj o komitetima:MAKEDONSKOM, KOSOVSKOM i HRVATSKOM, sastavljen po podacima prikupljenim u toku drugog tromesečja 1937. godine,- s molbom za uviđaj.

Molim, da se ovaj izveštaj uzme u detaljno razmatranje i pšreko Vaših izvora proveri ovo što je $u$ istom navedeno, pa zasebnim aktom izvesti Glavni Đeneralštab o rezultatu provere, kao i podacima sa kojima raspolažete a ne slažu se sa iznetim sadržajom.

Po zapovesti Načelnika Glavnog Đeneralštaba V.D. NAČELNIKA art. Pukovnika za đ-štab poslove

Potpis: ${ }^{3}$

Dostavljeno: prvom ađutantu Njegovog Veličanstva kralja, ministru vojske i mornarice, ministrima inostranih i unutrašnjih poslova, komandantima 1,2,3,4,5 armije, komandantu mornarice, komandantu granične trupe, komandantima Potiske, Zetske, Jadranske, Vrbaske, Vardarske, Kosovske, Bregalničke, Savske, Dravske, Osečke, Moravske i Timočke divizijske oblasti, vojnim izaslanicima u: Arbaniji, Austriji, Bugarskoj, Grčkoj, Italiji, Mađarskoj, Nemačkoj, Rumuniji, Turskoj, Francuskoj i Čehoslovačkoj, načelniku operativnog odelenja Glavnog đeneralštaba, M.Lj. J.

III.

\section{HRVATSKI KOMITET}

1) Rad Hrvatskog komiteta u Austriji.

U toku meseca aprila, maja i juna tg. nisu dobiveni nikakvi izveštaji o radu i aktivnosti ovoga komiteta u Austriji.

2) Rad Hrvatskog komiteta u Italiji.

Povodom likvidacije ustaške organizacije u Italiji zbog postignutog sporazuma između Beograda i Rima, u hrvatskoj emigraciji se pretresa mogućnost reorganizacije emigrantske akcije u slučaju mogućnosti da akcija ustaša u emigraciji bude u Italiji onemogućena.

Kao jedno od najvažnijih pitanja ističe se pitanje naimenovanja novog šefa organizacije, koji bi kao „zamenik Poglavnika“ vodio dalje poslove. Kandidati su: D-r. BUDAK i D-r. ARTUKOVIĆ, ali za drugog postoji mišljenje da ne bi bio najpogodniji jer je odan piću, dok se smatra da Budak nije dovoljno inteligentan i da bi svakako upropastio organizaciju. Ipak se veruje, da će Budak biti naimenovan za zamenika.

Zbog pitanja likvidacije ustaške organizacije u Italiji, u hrvatskoj emigraciji se živo pretresa pitanje osnivanja jedne nove revolucionarne organizacije i ova

Potpis je, kao i na ostalim dokumentima, nečitak. 
se mogućnost diskutuje u njihovim krugovima, jer se smatra, da ustaška organizacija pod svojim današnjim nazivom neće moći dalje da radi zbog mera koje sada preduzimju italijanske vlasti. I iz emigrantskih centara u Severnoj i Južnoj Americi insistira se na stvaranju jedne nove organizacije, a izgleda, da i tamošnji hrvatski listovi otvoreno zastupaju ovu ideju.

Povodom vesti da Pavelić održava veze sa prijateljima i jednomišljenicima van Italije, a naročito sa JOSIFOM BILJANOM, radi pripreme neke nove akcije i organizacije, dobiven je izveštaj iz pouzdanog izvora, da ova vest ne odgovara istini i da, u poslednje vreme Pavelić nije bio u mogućnosti, niti da održava veze niti da se bavi poslom organizacije.

Prema najnovijim obaveštenjima potvrđuju se raniji izveštaji dobiveni iz raznih izvora da je GUSTAV PERČEC ubijen u Italiji od strane Servacijevih ljudi i to posle publikovanja izjave JELKE POGORELEC i njegove date izjave. Smrtnu presudu Perčeca potpisao je Servaci.

Advokat IVAN GLIGA u poslednje vreme je više puta dolazio u Zadar i uvek se sastajao sa poznatim ustašom ANDROM RELJOM. Iako se Gliga predstavlja kao punomoćnik Reljin kod naših sudova, postoji mišljenje, da je to samo izgovor, a da je on u stvari Reljin poverenik.

Od strane nadležnih vlasti traženo je da se imenovanome, čija je delatnost štetna po interese naše države, oduzme pogranična karta i ne izdaje u buduće pasoš za inostranstvo što je i učinjeno.

Prema jednom podatku dobivenom iz vrlo ozbiljnog izvora, na ostrvima: Lipari, Stromboli i Điljio, nalazi se 426 emigranata, u raznim drugim mestima 61 istaknutijih ličnosti i najzad 23 desidenta, koji se sa ostalima nisu slagali.

Prema profesiji emigranti su:

337 seljaka, 77 radnika, 35 mornara, 17 studenata, 12 trgovaca, 10 oficira, 2 novinara, 6 ostalih profesija, 6 žena, 8 dece.

Svega 510 osoba.

Svi istaknutiji emigranti (61) konfinirani su sada u grupama po dvojica u raznim mestima u unutrašnjosti Italije, koja su ne samo daleko od naše granice, već su udaljena čak i od italijanske obale Jadranskog mora.

Od istaknutijih emigranata sada se nalaze: a) PAVELIĆ sa ženom i porodicom u Sijeni; b) KVATERNIK u Izerniji- pokrajina Kampobaso; v) VJEKOSLAV SERVACI sa ženom ANOM u Luki; g) NARCIS JESENSKI u Avelinu; d) EMIL LAHOVSKI na ostrvu Đilio.

Do sada je oko 20 emigranata tražilo da se vrate u zemlju, a 21 njih pak žele da idu u inostranstvo, među kojima je od poznatijih jedino Narcis Jesenski.

3) Rad Hrvatskog komiteta u Mađarskoj.

Na ponovnu molbu Perčevića da se vrati u Mađarsku, mađarske vlasti su imenovanoga izvestile, da se on kao mađarski državljanin može vratiti u Mađarsku, 
ali da će tamo biti pod nadzorom i da neće moći putovati u inostranstvo. Perčević je odustao da pod ovim uslovom dođe u Mađarsku.

Na nadležnom mestu u Mađarskoj doneta je odluka, da se nijednom od kompromitovanih članova ustaške organizacije ne dozvoli povratak u Mađarsku. Ova je odluka donesena obzirom na nov položaj ustaša u Italiji i na mogućnost, da ustaše koji su ranije boravili u Mađarskoj zatraže da im se dozvoli da iz Italije dođu u Mađarsku.

4) Rad Hrvatskog komiteta u Francuskoj.

U Parizu u ulici 42 Vašingtona, kod društva: Société des Pétroles Jupiter (telefon Elysées 90-10, 99-10, 90-20) nalazi se štab terorističkih ustaša. U ovaj štab svraćaju svi teroristi i njihovi agenti u prolazu kroz Pariz, radi dobijanja potrebnih instrukcija i dokumenata, za obavljanje poverenih im misija.

O prednjem su nadležni obavešteni.

5) Rad Hrvatskog komiteta u Nemačkoj.

Hrvatski emigranti: JELIĆ, LORKOVIĆ i ARTUKOVIĆ internirani su od strane nemačkih vlasti u Bavarskoj.

Preduzete su mere kod nemačkih vlasti da ova trojica emigranata budu internirani negde u Pruskoj, dakle više na severu Nemačke a ne u Bavarskoj kako bi se što više udaljili od naše državne teritorije i bili jače izolovani. Nemačke vlasti obećale su da će molbi izići u susret.

KRAJ

Dokument $2^{4}$

Kraljevina Jugoslavija, Glavni Đeneralštab, Obaveštajno odelenje, Str.pov. Đ. Ob. Br 1699, 23.10. 1937. g.

Vojnom izaslaniku-Arbanija

Tromesečni izveštaj o komitetima: MAKEDONSKOM, KOSOVSKOM i HRVATSKOM za mesec VII, VIII i IX 1937. g.

U prilogu pod/1, dostavlja se tromesečni izveštaj o komitetima: MAKEDONSKOM, KOSOVSKOM i HRVATSKOM, sastavljen po podacima prikupljenim u toku trećeg tromesečja 1937 godine, - s molbom za uviđaj.

Molim, da se ovaj izveštaj uzme u detaljno razmatranje i preko Vaših izvora proveri sve što je $u$ istom navedeno, pa zasebnim aktom izvesti Glavni Đeneralštab o rezultatu provere, kao i o podacima sa kojima raspolažete a ne slažu se sa iznetim sadržajem.

Po zapovesti Načelnika Glavnog Đeneralštaba, V.D. NAČELNIKA, art. pukovnik za đ-stab poslove,

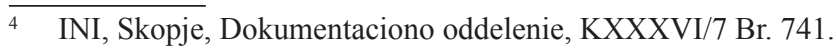


Potpis:

Dostavljeno: prvom ađutantu Njegovog Veličanstva kralja, ministru vojske i mornarice, ministrima inostranih i unutrašnjih poslova, komandantima 1,2,3,4,5 armije i komandantu mornarice, komandantu granične trupe, komandantima Potiske, Zetske, Jadranske, Vrbaske, Vardarske, Kosovske, Bregalničke, Savske, Dravske, Osečke, Moravske i Timočke divizijske oblasti, vojnim izaslanicima u: Arbaniji, Austriji, Bugarskoj, Grčkoj, Italiji, Mađarskoj, Nemačkoj, Rumuniji, Turskoj, Francuskoj i Čehoslovačkoj, načelniku operativnog odelenja Glavnog đeneralštaba, M.Lj. J.

\section{HRVATSKI KOMITET}

1) Rad Hrvatskog komiteta u Austriji.

Predstavniku komunističke partije za Balkan Kosti Gradčanovu, stavljeno je u dužnost da u Beču organizuje jednu konferenciju, na kojoj bi uzeli učešća pretstavnici hrvatskih terorista-ustaša, VMRO-mihailovista i jugoslavenskih i bugarskih komunista. Konferencija treba da se održi krajem septembra ili početkom oktobra tg. i na istoj treba da se reši pitanje i mogućnost saradnje pomenutih organizacija u odnosu na Jugoslaviju i Bugarsku.

Predlog za saziv ove konferencije dostavljen je Moskvi od strane vođstva ustaša. Lice koje bi uzelo učešća od strane mihailovista, pominje se Dimitri Cilev. Mihailovisti se plaše da će im ovaj savez sa komunistima pogoršati položaj u Bugarskoj.

Što se tiče terorističke akcije protivu naše države, govori se da su ustaše, koji imaju sredstava ali nemaju podobnih ljudi, voljni pomoći svaku akciju mihailovista iz inostranstva, ali da prvenstveno traže dokaze delom, tj. da su mihailovisti za to sposobni.

2) Rad Hrvatskog komiteta u Italiji.

Netačna je tvrdnja da su emigranti u Italiji rastureni po celoj zemlji.

Situacija kod hrvatskih emigranata u Italiji je ovakva:

Pošto su osetili da Italija ne samo da više ne računa na njihovu pomoć, već su joj i na teretu i prvom zgodnom prilikom gledaće da ih se definitivno oslobodi; kod emigranata na Liparima pojavilo se jako nezadovoljstvo. U mestu Liparima počeli su čak i da se obraćaju pretsedniku opštine za pomoć i da bune stanovništvo. Neposredno zatim zavladala je zaraza tifusa među njima, od koje su umrla 6 lica i 1 se obesilo, posle čega su najzad počeli da štrajkuju glađu.

Da bi se stalo ovome na put, a pošto se na intervenciju sa naše strane odustalo od rasturanja emigranata po Italiji, rešeno je da se sa Lipara uklone organizatori pobune. I tako je od njih 523 koliko ih je bilo na Liparima izdvojeno 50 i poslato na ostrvo Sardiniju i tamo raspoređeni u grupama od po pet, po utvrđenjima daleko od mora. 10 avgusta tg. završeno je sa prebacivanjem ovih. 
Gro ostalih emigranata na Liparima, zbog ovih mera preduzetih od strane Italijana, umirio se, bojeći se da su im drugovi otposlati u Italijansku Afriku. Od strane vlasti nad njima je pooštrena cenzura i nadzor.

Hrvatskim emigrantima u Italiji na intervenciju naših vlasti, zabranjeno je rasturanje iz logora kao i zaposlenje istih.

Za povratak u zemlju javilo se do sada 31 emigrant. Veruje se da i sama italijanska vlast propagira da se ustaše ne vrate u Jugoslaviju, a naročito što se tiče onih glavnih za koje i tvrde italijanske vlasti, da se od njih niko nije javio za povratak. Po svemu sudeći Italijani ne žele olako ispustiti iz svojih ruku ustaše, bojeći se da isti ne odaju raniji rad italijanskih vlasti.

Italijani tvrde da emigranti nalazeći se sada u Italiji nisu imali ničega zajedničkog sa terorističkom akcijom, kojom su rukovodili: Pavelić, Kvaternik i ostali vođe iz inostranstva, a ne iz Italije.

Što se tiče ostalih emigranata oni se nalaze rastureni po 2-3 u grupama po Kalabriji, pod jakom kontrolom mesnih vlasti u nemogućnosti da pobegnu ili se dopisuju bez cenzure.

Pavelić je još uvek u Sijeni, ali je odatle premešten u vilu „Pogiarelo“, koja je dobro čuvana i kontrolisana. Po svemu sudeći o mestu njegovog boravka ne znaju ništa ostali emigranti.

U Italiji je koncem meseca avgusta i početkom septembra tg. izvršen nov razmeštaj ustaša, razdvajajući ustaše koji su dotle bili raspoređeni po manjim grupama, i to većinom po brdovitim krajevima Sardinije i Sicilije.

Sem toga u poslednje vreme počele su italijanske vlasti vrbovati dobrovoljce za svoje trupe u Španiji između ustaša, ali su ustaše sve pozive odbile.

Potpisivanjem pakta između Italije i naše Kraljevine, moral ustaške organizacije jako je pao. Uprava ustaškog saveza u Brislu stoga se odmah obratila vođstvu Pavelićevog pokreta, tražeći obaveštenja i dalje instrukcije za rad, izveštavajući ga istovremeno o nastalom komešanju među članovima organizacije.

U tom cilju upućen je od strane vođstva delegat, MARUŠIĆ STEFAN, koji se našao sa trojicom glavnih članova uprave i to: predsednikom Jakovom Križanićem, tajnikom Marijanom Batinićem, i nadtabornikom Nikolom Grabovcem. Gde je sastanak izvršen i šta je na istom odlučeno, nije poznato.

Po Marušićevom hapšenju u Parizu, ponovo je nastalo komešanje među članovima ustaškog saveza, tim pre i više, što su neki iz uprave istog saveza bili doznali, da je Pavelićev delegat dolazio u Belgiju, te imao sastanak sa trojicom ustaša o čemu isti nisu hteli obavestiti druge, pa su razdraženi i nezadovoljni ovakvim postupcima svojih vođa, tražili da se odmah sazove sednica, jer inače odavna nije bila održana. Na ovoj sednici, sazvanoj na zahtev nezadovoljnika, dolazilo je do vrlo žučnih prepirki, tako da su na kraju većina bili podneli ostavke. Da ne bi dali rđav primer drugima te na taj način još više demoralisali svoje članove, svi oni koji su bili podneli ostavke, privoljeni su da i dalje ostanu u upravi, tako 
da je incident bio regulisan istupom iz članstva samo jednog člana uprave, Pero Brka, s tim da se ponovo obrate na vođstvo i traže instrukcije za rad. Malo posle ovih incidenata pojavio se najednom u Serengu, Rade Nikić, poznati crnogorski separatista i jedan od dopisnika Pavelićevog lista „Nezavisna Hrvatska država“.

Nikić se obratio na opštinu u Serengu i molio da mu se dozvoli boravak od nekoliko dana, bez prijave i promene mesta boravka a sve radi obavljanja izvesnih svojih ličnih poslova, što mu je i odobreno.

Nikić je u toku tih nekoliko dana u više mahova posetio ustaški dom i stanove glavnih ustaša, te ih je tako u grupama skupljene kuražio, iznoseći, da pakt jugoslovensko-italijanski ne pretstavlja ništa drugo nego jedan diplomatski gest Italije, koji nije nepoznat Paveliću, a koji je za momenat bio neophodno potreban iz razloga konflikta u Španiji; da je ovom paktu jugoslovensko- italijanskom prethodio jedan tajni pakt između Pavelića i Musolinija, tako da čim bude pitanje Španije likvidirano, da će se Italija okrenuti i svim silama pomoći oslobodilački ustaški pokret. Nikić je tvrdio da je sve ovo poznato i Dr. Mačeku, tvrdeći da je primio pismo od Sekule Drljevića, narodnog poslanika na listi Dr. Mačeka, za Crnu Goru, u kome ga obaveštava da Dr. Maček radi po instrukcijama Pavelićevim, te da ako do ovog momenta nije došlo do revolucije u Jugoslaviji, to je iz razloga što prilike u celom svetu nisu normalne, a i da se čeka „Pavelićev mig“. Prema daljim pričanjima Nikićevim, nema za sada nego samo jednu jedinu dužnost, a to je da održi stanje u državi onakvo kakvo je za momenat, te da čim bude dobio nalog od Pavelića, da će revolucija planuti u Jugoslaviji.

21 avgusta tg. zadarska kvestura izvršila je premetačinu u kući kod Relje Andrije, poznatog ustaškog organizatora u Zadru, kojom je prilikom zaplenila sav nalazeći se ustaški materijal kod imenovanog, među kojim je bilo i nekoliko ustaških revolvera.

Kvestura je kaznila Relju zbog ustaške akcije sa 5 dana zatvora. Sem toga kvestura je zavela i kontrolu nad korespondencijom koju prima Relja, a koje imaju veze sa ustaškom akcijom $\mathrm{i}$ iste pleni.

Po svemu sudeći, izgleda da je sada glavni ustaški stan u Roterdamu (Holandija) a da se banditski vođa sada nalazi u Južnoj Americi.

Relja Andrija nameran je da nekud uskoro otputuje, pa se misli da će otići u Roterdam.

Zbog zavedene kontrole od strane italijanskih vlasti, u buduće ustaški materijal neće se slati više preko Relje, nego preko nekog drugog lica, koje je za sada još nepoznato.

3) Rad Hrvatskog komiteta u Mađarskoj.

Neraspoloženje hrvatskih emigrantskih krugova u Mađarskoj prema inž. Avgustu Košutiću sve više uzima maha. U tim krugovima se govori, da bi za slučaj obnavljanja terorističke akcije Dr. Košutić bio njena prva žrtva. 
Prema dobivenim obaveštenjima mađarski đeneralštab stoji na gledištu da sa licima koja su pripadala ustaškoj organizaciji više ne treba raditi, i da za eventualni novi rad treba naći i nova lica. $S$ te tačke gledišta Klobučarić bi mogao biti pogodna ličnost, jer nikad nije sarađivao sa naznačenom terorističkom organizacijom. On je ranije aktivno učestvovao u radu prve hrvatske emigracije.

4) Rad Hrvatskog komiteta u Americi.

Ustaška akcija ponovo je oživela. U poslednjih nekoliko meseci zapaža se naročita živost u organizovanju, pripremanju, vežbanju i propagandi.

Usled promenjene političke situacije za ovo vreme, centar rada prenosi se sve više na Američki kontinent, gde se sprovodi najživlja agitacija i organizuju naši iseljenici Hrvati, angažujući ih za ustašku stvar. Naročito jake ustaške organizacije postoje u Argentini i Kanadi, koje su organizacije potpuno vojnički formirane, uniformisane u ustašku uniformu i potpuno naoružane modernim oružjem. Članovi formirani u jedinice stalno izvode vežbanja. Rad se izvodi javno, ali pod vidom hrvatske organizacije za fizičko vaspitanje.

Organizacija Hrvatskog domobrana iz Sev. Amerike tražila je od emigrantske organizacije u Evropi, da joj se pošalje po jedan dobar organizator.

Prema dobijenim obaveštenjima, emigrant Mihajlo Sertić, koji od pre izvesnog vremena živi u Budimpešti, preduzeo je korake da on bude tamo poslat, ali za njegov odlazak ima malo izgleda. Mnogo je verovatnije, da će emigranti Artuković i Lorković, koji i inače žele da idu u Ameriku, preuzeti službu organizatora.

Od strane ustaša iz Amerike osuđen je na smrt bivši šef policije u Zagrebu g. Bedeković. Ko treba ovu odluku da privede u delo i da je izvrši, kao i kada se ista ima izvršiti, nije se moglo ustanoviti.

Koncem meseca septembra tg. Mladen Lorković i Andrija Artuković begstvom su napustili Nemačku i otišli u Ženevu. Svi su izgledi da obojica emigranata imaju nameru da uskoro otputuju u Ameriku.

KRAJ.

\section{Dokument $3^{5}$}

Kraljevina Jugoslavija, Glavni Đeneralštab, Obaveštajno odelenje, Str.pov. Đ. Ob. Br. 84

22.1. 1938.

Vojnom izaslaniku u Arbaniji

Tromesečni izveštaj o komitetima: MAKEDONSKOM, KOSOVSKOM i HRVATSKOM za mesece oktobar, novembar i decembar $1937 \mathrm{~g}$.

U prilogu pod/1, dostavlja se tromesečni izveštaj o komitetima: MAKEDONSKOM, KOSOVSKOM i HRVATSKOM, sastavljen po podacima prikupljenim u toku četvrtog tromesečja 1937 godine, - s molbom za uviđaj.

5 INI, Skopje, Dokumentaciono oddelenie, KXXXVI/7 Br. 742. 
Molim, da se ovaj izveštaj uzme u detaljno razmatranje i preko Vaših izvora proveri sve što je $u$ istom navedeno, pa zasebnim aktom izvesti Glavni đeneralštab o rezultatu provere, kao i o podacima sa kojima raspolažete a ne slažu se sa iznetim sadržajem.

Po zapovesti Načelnika Glavnog Đeneralštaba, NAČELNIK, art. brigad. Đeneral za đ-šst.pos.

Potpis:

Dostavljeno: prvom ađutantu Njegovog Veličanstva kralja, ministru vojske i mornarice, ministrima inostranih i unutrašnjih poslova, komandantima 1,2,3,4,5 armije i komandantu mornarice i komandantu granične trupe, komandantima Potiske, Zetske, Jadranske, Vrbaske, Vardarske, Kosovske, Bregalničke, Savske, Dravske, Osečke, Moravske i Timočke divizijske oblasti, vojnim izaslanicima u: Arbaniji, Austriji, Bugarskoj, Grčkoj, Italiji, Mađarskoj, Nemačkoj, Rumuniji, Turskoj, Francuskoj i Čehoslovačkoj, načelniku operativnog odelenja Glavnog đeneralštaba, M.Lj. J.

\section{HRVATSKI KOMITET}

1. Rad Hrvatskog komiteta u Americi.

5, 6 i 7 septembra 1937 godine u Vašingtonu, na kongresu Makedonske organizacije u Indianapolisu, uzelo je učešće nekoliko stotina lica. Tom prilikom sakupljeno je oko 4. 000 /-dolara za nastavak još energičnije borbe protiv Beograda a u sporazumu sa hrvatskoustaškim- domobranskim pokretom. Prilikom kongresa izdata je spomenica od preko 200 strana, većinom oglasa na kojima je dobiveno isto oko 1000 dolara.

U poslednje vreme u znatnoj je meri pojačana akcija udruženja Pavelićevih pristalica „Hrvatski Domobran“ u Južnoj Americi. Oni se pod vidom sportskih i humanih organizacija pripremaju za ustašku akciju. Nedavno je listu „Hrvatski Domobran“ pojačan tiraž, ali se još ne zna odakle im dolaze potrebna materijalna sredstva.

U vezi sa poboljšanjem naših odnosa sa Italijom i onemogućenjem daljeg rada protivu naše države, javila se među emigrantima u Južnoj Americi težnja, da se Pavelić nekako dovede u Ameriku i tamo stavi na čelo pokreta. Na bekstvu Pavelića iz Italije, pored emigranata u Americi, radi se i u Evropi. Na čelu ove akcije je bivši potpukovnik Ivan Perčević, koji stalno živi u Beču, ali često dolazi u Grac ili odlazi u Mađarsku.

Pošto su naše vlasti o ovome bile obaveštene, preduzete su potrebne mere kod italijanskih vlasti, da se nad Pavelićem pojača kontrola i bezuslovno onemogući njegovo bekstvo. Kako su već i Italijani imali o ovome podataka, pojačan je broj policajaca u Pavelićevoj vili u Sijeni, a nedavno je u istoj obrazovana i karabinjerska stanica. Osim toga, njemu je sada smanjena i mogućnost slobodnog kretanja i to uvek i jedino u pratnji organa policije. 
Sklapanjem prijateljskog ugovora između Kraljevine Jugoslavije i Italije, italijanske vlasti zabranile su ustaške logore u Severnoj Italiji, a većina ustaša rastureno je po unutrašnjosti Italije i delom i po drugim državama. Izvesnom broju ustaša, pogotovu onima koji su imali ulogu instruktora i vežbali članove ustaških organizacija u rukovanju sa oružjem, bombama i td. omogućeno je da se isele za Ameriku. Najviše ih ima danas u Argentini i Kanadi, gde je pomenuta organizacija formirana u čisto vojničkom duhu: članovi nose uniformu, naoružani su: puškama, bodežima i revolverima.

Neverovatno je, kako se razvila agitacija u poslednje vreme u svima krajevima Amerike, koju vode članovi ustaške organizacije među našim iseljenicima, koji šire razne alarmantne vesti o: raspadu Jugoslavije i nesnosnim političkim prilikama koje u njoj vladaju, ubeđujući naše iseljenike, da će ranije ili docnije doći do osnivanja samostalne hrvatske države koja će se prostirati sve do Zemuna i Ulcinja.

Direktive primaju od Dr. Pavelića, dok glavni deo vođstva već se nalazi u Americi. Među iseljenicima prikupljaju se mesečni prilozi iz kojih se izdržavaju pomenute organizacije.

Sve ustaške organizacije, koje se bave vojničkim vežbama prijavljene su amerikanskim vlastima kao društva koja se bave fizičkim vaspitanjem.

U Severnoj Americi „Ustaška akcija“ nije toliko raširena, ali prema prikupljenim podacima izgleda, da se prilično veliki doprinos u novčanim potporama dobiva baš od našeg življa koji stalno živi u Severnoj Americi.

2. Rad Hrvatskog komiteta u Austriji.

U krugovima hrvatske emigracije u Austriji nije bilo značajnijih momenata u toku meseca oktobra, novembra i decembra 1937 godine.

Sa jedne strane se tvrdi, da se Perčević dopisuje sa Pavelićem, ali sadržaj ove prepiske nije se mogao doznati.

Po svoj prilici, ovde se ne može raditi o nečemu izvanredno važnom, jer je emigrantska akcija uopšte zbog političkih prilika u Austriji prilično zamrla.

Zna se pozitivno da za vezu između Pavelića i Perčevića služi udova potpukovnika Dujića, kojoj se ne čine nikakve smetnje u pogledu izdavanja putnih isprava, te joj je stoga i poverena ta misija.

Nedavno je bila u Italiji ponovo, odakle je donela neke važne poruke, koje se u glavnom odnose na stav ustaške organizacije prema nekim političkim strujama u Hrvatskoj.

Po svemu sudeći, čovek koji je najopasniji i jedino sposoban da ponovo pokrene ustašku akciju jeste Ivan Perčević, nastanjen u Beču. On radi na proširenju ove akcije u Americi, osim toga stalno pokušava da dođe u vezu sa ustašama u Italiji.

Govori se da je nedavno bio u Gracu radi prijema poruke od strane Budaka, interniranog u Salernu kraj Napolja. 
Avgusta meseca 1937 godine, opet, u Salerno je dolazila jedna gospođa, koja je Dr.Budaku dovela ćerku iz Austrije. On je od italijanskih vlasti prvo tražio da odobre njegovoj ženi odlazak po ćerku, ali ove to nisu odobrile, sumnjajući da će ona tom prilikom doći u vezu sa Perčevićem i stvarno pretstavljati kurira između njega i emigranata u Italiji.

Po svemu sudeći gospođa koja je dovela kćer Dr. Budaku iz Austrije, jeste gospođa Dujić, supruga poznatog emigrantskog vođe, pokojnog pukovnika Dujića.

Italijanske vlasti tvrde, da o ovome nemaju podataka, pošto zbog velikog turističkog saobraćaja ne beleže ko sve prelazi austro-italijansku granicu.

\section{Rad Hrvatskog komiteta u Italiji.}

Andrej Relja koji je u Zadru radio protiv naše države uhapšen je 4 oktobra 1937 godine po našem traženju, od strane italijanskih vlasti kao i zbog terorističke akcije kažnjen sa mesec dana zatvora, stim da će, ako i nadalje nastavi sa ovakvim radom, biti konfiniran negde u unutrašnjosti Italije.

U poslednje vreme proneo se glas, da je Kvaternik/ interniran u Izerniji, provinciji Kampobaso/ sa još 24 ustaša prešao iz Italije u Austriju a delom i u Nemačku. Na osnovi svih provera, ova vest ne odgovara istini.

Jedini ustaši koji su uspeli da pobegnu jesu:

a) - Stjepan Marušić, koji je još meseca jula 1937 godine prebegao u Francusku i

b) - Muhamed Pilav iz Foče, koji je u toku meseca oktobra 1937 godine pobegao iz logora na Liparima i do sada nije mogao biti uhvaćen. On je u više mahova tražio da bude vraćen u zemlju, ali kako odobrenje nikako nije pristiglo, pobegao je u uverenju da mu italijanske vlasti ne odobravaju povratak. Po svoj prilici će pokušati da dođe u Jugoslaviju.

Polovinom meseca oktobra 1937 godine na Liparima je ponovo odreklo poslušnost 11 ustaša, koji su pokušali da pobegnu iz glavnog logora. $U$ tome su sprečeni, uhvaćeni i svi osuđeni na po tri meseca zatvora pa će po izdžanju kazne opet biti vraćeni u logor na Liparima.

Zbog svega ovoga Italijani stalno insistiraju na što bržem rešenju ustaškog pitanja, tvrdeći da će ono biti definitivno likvidirano tek povratkom u zemlju najvećeg broja ustaša, kako je u ostalom i rešeno i pitanje crnogorskih, arbanskih, bugarskih i antifašističkih emigranata.

Dokle god su bili u inostranstvu oni su pretstavljali izvesnu opasnost za zemlju i omogućavali neprijateljima da time propagiraju protiv države iz koje su pobegli. Jednom repatrirani, oni prvo gube oreol mučenika i borca za plemenske ideale, a osim toga- razočarani i uvidevši kako je nesigurna i slaba tuđa pomoć- ne pretstavljaju više ni u zemlji nikakvu opasnost.

Odugovlačenjem rešenja ovoga pitanja ide se na ruku agitaciji Pavelićevih ljudi protiv povratka u Otadžbinu, pošto će se, kako oni uveravaju, uskoro opet otpočeti sa terorističkom akcijom. Ako jednom definitivno izgube nadu na povra- 
tak, ovi ljudi biće sposobni na sve i očevidno je da će ovakva akcija tada imati punog uspeha.

Broj ustaša kojima je do sada odobren povratak iz Italije u našu zemlju iznosi 25. To su: Bubalo Ante, rođen 1905 u Trebiži, srez Stolac; Petričević Mate, 1898 Lovreč, srez Imotski; Vlašica Marko 1907 Osojnik, srez Dubrovački; Bilankov Ante, 1909g. Grohota, srez Splitski; Grubač Milan, 1902g. Posinka, srez Jastrebarski; Zadarić Petar, 1899g. Imotski; Lončar Zvonimir, 1911g. u Bolu na Braču; Čačija Ivan, 1896g. Livno; Franulović Lovre, 1905g. Blato; Francetić Jure, 1912g. Otočac; Pekas Josip, 1906g. Gradina, Šibenik; Kurtin Krsto, 1907g. Kali, Preko; Lončar Nikola, 1907g. Zagvozd, Imotski; Mustapić Mato, 1905g. Lovreč, Imotski; Črić Stjepan, 1900g. Lovreč, Imotski; Olujić Ante, 1908g. Opanci, Split; Čarić Andrija, 1899g. Stari Grad, Benkovac; Šuto Ante, 1905g. Zmijevica, Imotski; Lujetić Andrija, 1907g. Split; Lončar Ljubomir, 1912g. Imotski; Šuman Mato 1909g. Komin, Metković; Čubretović Jakob, 1906g. Vrbanje, Hvar; Benković Frano, 1906g. Babino polje, Dubrovnik i Frleta Šime, 1912g. Bibinje, Biograd n/m.

Prva grupa od 12 ustaša već je repatrirana i ovi treba da se nastane u mesta koja im je Ministarstvo unutrašnjih poslova pojedinačno odredilo za boravak, tako:

Kurtin u Kale, srez Preko; Vlašica u Osojniku, srez Dubrovački; Pekas u Gradini, srez Šibenik; Grubač u s. Posinka, srez Jastrebarski; Zaradić i Petričević u Lovreču; Bilankov u Grohote, srez Splitski; Francetić u Otočcu; Bubalo Ante u Trebižatu; Franulović u Blatu na Korčuli; Čačija u Suhaču, srez Livno i Lončar u Imotskom.

4) Rad Hrvatskog komiteta u Mađarskoj.

U toku tromesečja oktobar, novembar i decembar 1937 godine nisu dobiveni nikakvi podaci o radu i aktivnosti ovoga komiteta.

Kraj

Dokument $4^{6}$

Kraljevina Jugoslavija, Glavni Đeneralštab, Obaveštajno odelenje, Str.pov. Đ. Ob. Br. 2142.

28.4. 1939.

ŠEFU 2. OTSEKA OBAVEŠTAJNOG ODELJENJA GLAVNOG ĐENERALŠTABA

Tromesečni izveštaj o komitetima: MAKEDONSKOM, KOSOVSKOM i HRVATSKOM za mesece JANUAR, FEBRUAR i MART $1939 \mathrm{~g}$.

U prilogu pod/1, dostavlja se tromesečni izveštaj o komitetima: MAKEDONSKOM, KOSOVSKOM i HRVATSKOM, sastavljen po podacima prikupljenim u toku prvog tromesečja 1939 godine, - na znanje i upotrebu.

$\overline{6}$ INI, Skopje, Dokumentaciono oddelenie, KXXXVI/7 Br. 748. 
NAČELNIK, konjički brigadni đeneral za đeneralštabne poslove

Potpis:

Dostavljeno: prvom ađutantu Njegovog Veličanstva kralja, ministru vojske i mornarice, ministrima inostranih i unutrašnjih poslova, komandantima 1,2,3,4,5 armije i primorske armijske oblasti, komandantu mornarice i granične trupe, komandantima Potiske, Zetske, Jadranske, Vrbaske, Vardarske, Kosovske, Bregalničke, Savske, Dravske, Osečke, Moravske i Timočke divizijske oblasti, vojnim izaslanicima u: Arbaniji, Austriji, Bugarskoj, Grčkoj, Italiji, Mađarskoj, Nemačkoj, Rumuniji, Turskoj, Francuskoj i Čehoslovačkoj, načelniku operativnog odelenja Glavnog đeneralštaba, M.Lj. J.

\section{HRVATSKI KOMITET}

1) Hrvatski komitet $u$ Americi

U toku 1938 godine od strane naših zvaničnih pretstavnika u Americi, učinjeno je sve, da se među našim iseljenicima- naročito u Pitsburgu i Pensilvaniji, spreči razoran rad domobranaca (sledbenika Pavelića dr. Ante). U ovom pogledu postignuti su veoma dobri rezultati, pošto je domobranski pokret među Hrvatima u Americi u rapidnom opadanju i isti će u doglednom vremenu biti primoran da sasvim likvidira.

Uspelo je se, da se sa položaja Glavnog tajnika domobrana, kao i iz uredništva lista „Nezavisna hrvatska država“ ukloni Došen Anton, koji je u toku poslednjih šest godina bio stvarni vođa i organizator domobranskog pokreta u Americi.

Na emigrante nastanjene u Mađarskoj gornji su glasovi izazvali veoma mučan utisak. Doskoro su pomenute organizacije smatrane kao stubovi hrvatskog separatističkog pokreta, pa se zato predviđa da će previranje koje je tamo nastalo, imati nepovoljnih posledica po celokupni hrvatski separatistički pokret.

Jelić dr. Branimir, na dan 4 februara t.g. parobrodom „Bremen“, prispeo je u Ameriku sa mađarskim pasošem. Ali iskrcavanje mu nije bilo dozvoljeno, već su ga tamošnje vlasti zadržale na ostrvu Elis.

Viši emigrantski sud u Sjedinjenim američkim državama, na dan 20 februara t.g. doneo je odluku, da se dr. Jeliću ne odobri ulazak u Ameriku. Zbog ovakvog rešenja, imenovani je otpočeo da štrajkuje glađu.

Po svemu izgleda, da nemačke vlasti nisu bile umešane u pomenuto bekstvo. Ali kako se pozitivno zna, da su iste više puta izjavljivale, da bi se vrlo rado oslobodile dr. Jelića, to se ipak sumnja da im pripreme bekstva nisu bile poznate.

Pozitivno je utvrđeno, da je dr. Jelić imao uspostavljenu vezu sa nekom poznatom mu osobom na prekookeanskom brodu „Bremen“, pošto je ovaj brod javio, da imenovani u kritičnom dobu nije putovao na pomenutom brodu za Ameriku, što je dokazano kao skroz neistinito.

Putovanje imenovanoga je u vezi sa obrazovanjem hrvatskog komiteta, čiji bi zadatak bio upoznavanje strane javnosti sa željama hrvatskih separatista za otcepljenje Hrvatske od Jugoslavije. 
Ovaj komitet, na čijem bi se čelu nalazio dr. Jelić, Artuković i vođstvo hrvatskog domobranstva u Americi, imao bi da se formira u Americi, ali bi ubrzo posle ovoga svoje sedište preneo u Bratislavu, koja bi kao prestonica nove slovačke države, imala da posluži uspešnoj separatističkoj akciji.

Saradnik „Makedonske tribune“, lični prijatelj Ivana Mihailova i pisac nekoliko brošura uperenih protivu nas i naše zemlje, Stojan Hristov, izgleda da je prekinuo saradnju sa makedonskim organizacijama u Americi.

Pretsednik makedonske političke organizacije u Indianapolisu, Pandil Šanev, na dan 26 januara t.g. izvršio je samoubistvo. Na ovaj način, nestala je vrlo važna ličnost sa pozornice revolucionarne aktivnosti američkih bugaraša.

Nedavno je naprasno umro u Pensilvaniji dr. K. Canev, bivši zamenik pretstavnika bugarske crkve u Americi. Ovaj je preko crkve za života davao najveću pomoć i podršku makedonskoj organizaciji u Americi.

\section{2) Rad Hrvatskog komiteta u Italiji}

Nema se nikakvih novih podataka o radu i aktivnosti emigranata u Italiji. Stanje $\mathrm{u}$ pogledu istih ostalo je nepromenjeno u odnosu na poslednji izveštaj podnet pod Str. Pov. Đ. Ob. Br. 97 od 22 januara 1939 godine.

3) Rad Hrvatskog komiteta u Mađarskoj

Ima se obaveštenje, da je 20 marta t.g. uveče, doputovao u Budimpeštu iz Brisla Artuković dr. Andrija pošto su mu belgiske vlasti otkazale dalji boravak u Belgiji.

Imenovani je u Budimpešti otseo kod emigranta Marka Došena, koji stanuje u ulici Sas Karolj broj 3.

U emigraciji u glavnom preovlađuje mišljenje, da za sada treba zauzeti stav posmatrača i sačekati dalji razvoj događaja, kako bi se videlo, na koji način Beograd i Zagreb misle da nađu rešenje za sporazum.

Emigranti, koji se nalaze u Mađarskoj zastupaju gledište, da dr. Mačeku ne treba stvarati nikakve teškoće, sve dotle, dok se on bude držao zahteva postavljenih od strane frankovaca. U slučaju da dr. Maček napusti ovaj program i pristane da učini izvesne ustupke, emigracija će se zajedno sa svojim jednomišljenicima u zemlji, svim silama usprotiviti stvaranju sporazuma koji ne bi bio u skladu sa frankovačkim idejama.

Po mišljenju emigranata, rad na stvaranju sporazuma Beograd-Zagreb, nailazi među frankovcima na nepovoljan prijem, pošto kod istih, iz razloga političkog prestiža, postoji želja, da i oni u tome sarađuju.

Emigranti dakle očekuju, da će ovi elementi pokušati na svaki način da ometu pregovore između Beograda i Zagreba, osim ako bi i oni u istima učestvovali.

U Mađarskoj, hrvatska emigracija frankovački orientisana, odlučno je protivna radu na sporazumu, i u njenim krugovima pomišlja se čak i na obnavljanje terorističke akcije u slučaju, da dr. Maček sporazumevanje sa Beogradom uputi jednim pravcem koji ne bi odgovarao njenim težnjama. 
Ima se obaveštenje, da u Mađarskoj postoji opet organizovana teroristička organizacija. Članovi organizacije su Jugoslaveni i Rumuni- emigranti, a dobar deo istih je rekrutovan i iz redova mađarskih robijaša koji su pušteni na slobodu pod uslovom da stupe u pomenutu organizaciju.

Centrala ove organizacije je u Budimpešti. Teroriste su većinom smeštene po vlastelinskim majurima duž jugoslovenske i rumunske granice. Pod nadzorom aktivnih oficira, redovno se vrše vežbe za njihov budući rad.

Glavni zapovednik ove organizacije je neki Samson. Vežbanja u radu terorista vrše se na taj način, što se postavljaju uvećani likovi ličnosti iz Rumunije i Jugoslavije, na koje se vežbaju u gađanju. Izrađene figure označavaju ličnosti koje su osuđene na smrt.

Prebacivanje ovih terorista u Jugoslaviju i Rumuniju, izvršiće se onda, kada nadležni nađu za potrebno. Teroristi će biti snabdeveni sa propisnim pasošima, dok će jedan deo biti prebačen pomoću organa mađarske granične straže, i to na taj način, što će im dotični organi dati znak gde i kada mogu preći graničnu liniju.

Prvi zadatak terorista biće, da u Jugoslaviju i u Rumuniju prebace i rasture brošure i letke, koje je izdala centrala u Budimpešti. Letci se imaju razdeliti Mađarima u Jugoslaviji i u Rumuniji. Sadržaj istih uliće Mađarima moralnu snagu da se pobune protiv vlasti i poretka u našoj zemlji. Izveštaj je u toku proveravanja.

4) Rad Hrvatskog komiteta u Belgiji

Jordan Čkatrov početkom meseca novembra 1938 godine prispeo je sa bugarskim pasošem u Brisel. Upisao se je na prava na briselskom univerzitetu. Stanuje u ulici Gašar br. 65, u nameštenoj sobi; živi povučeno, nigde ne izlazi. Prima veliku korespondenciju iz Bugarske i Amerike.

Kraj

\section{Dokument $5^{7}$}

Kraljevina Jugoslavija, Glavni Đeneralštab, Obaveštajno odelenje, Str.pov. Đ. Ob. Br. 2142.

31.7. 1939.

ŠEFU 2. OTSEKA OBAVEŠTAJNOG ODELJENJA GLAVNOG ĐENERALŠTABA

Tromesečni izveštaj o komitetima: MAKEDONSKOM, KOSOVSKOM i HRVATSKOM za mesece APRIL, MAJ i JUN $1939 \mathrm{~g}$.

U prilogu pod/1, dostavlja se tromesečni izveštaj o komitetima: MAKEDONSKOM, KOSOVSKOM i HRVATSKOM, sastavljen po podacima prikupljenim u toku drugog tromesečja 1939 godine, - na znanje i upotrebu.

INI, Skopje, Dokumentaciono oddelenie, KXXXVI/7 Br. 749 
NAČELNIK, konjički brigadni đeneral za đeneralštabne poslove

Potpis:

Dostavljeno: prvom ađutantu Njegovog Veličanstva kralja, ministru vojske i mornarice, ministrima inostranih i unutrašnjih poslova, komandantima 1,2,3,4,5 armije i primorske armijske oblasti, komandantu mornarice i granične trupe, komandantima Potiske, Zetske, Jadranske, Vrbaske, Vardarske, Kosovske, Bregalničke, Savske, Dravske, Osečke, Moravske i Timočke divizijske oblasti, vojnim izaslanicima u: Arbaniji, Austriji, Bugarskoj, Grčkoj, Italiji, Mađarskoj, Nemačkoj, Rumuniji, Turskoj, Francuskoj i Čehoslovačkoj, načelniku operativnog odelenja Glavnog đeneralštaba, M.Lj. J.

\section{HRVATSKI KOMITET}

1) Rad Hrvatskog komiteta u Americi

Na dan 9 aprila t.g. vođe Makedonstvujuščih u Americi, održale su tajan sastanak u Akronu,- država Ohajo. Na ovom sastanku raspravljalo se je o situaciji u Evropi u vezi sa poslednjim događajima u Češko-Slovačkoj i u Arbaniji.

Prema istom izveštaju, vođe makedonske političke organizacije u Americi, dobile su naređenje da napuste dosadašnju političku borbu za nezavisnost Makedonije, a da upregnu sve sile za prisajedinjenje Makedonije Bugarskoj. Nagovešteno im je, da je nastupio čas da rade svim silama na ostvarenju bugarskog narodnog ideala,- tj. na stvaranju velike i ujedinjene Bugarske.

Gornji savet je usvojen na pomenutoj konferenciji i na osnovi toga biće promenjen pravac pisanja „Makedonske tribune“. Na konferenciji se tvrdilo, da su Nemačka i Italija dale garantiju, da će se Makedonija prisajediniti Bugarskoj, te je glavna uprava Makedonske političke organizacije ovlašćena da šalje u tom smislu rezolucije g.g. Hitleru i Musoliniju.

$\mathrm{Na}$ dan 16 aprila t.g. održana je u zavodu časnih sestara Sv. Vinka na Dok Sudu u Buenos Airesu glavna skupština „Hrvatske katoličke zajednice“ pod vođstvom fra Blaža Štefanića. U prvi izabrani odbor ušli su isključivo članovi tamošnje ustaške organizacije. Na skupštini je učestvovalo oko 70 lica.

Istoga dana sazvala je ustaška organizacija u Buenos Airesu „Hrvatski Domobran“ veliku hrvatsku narodnu skupštinu u jednoj dvorani na Dok Sudu. U prkos propagande i reklame za ovu skupštinu, istoj je prisustvovalo svega nekoliko stotina lica.

Pavelićev izaslanik Ante Valenta i starešina Domobrana za Južnu Ameriku Mate Vujašić, isticali su svojim govorima potrebu za zbijanjem hrvatskog narodnog fronta, pošto je sadašnja politička situacija u Evropi pogodnija nego ikada ranije za ostvarenje hrvatske nezavisne države. Valenta je napadao dr. Mačeka „da se je prodao Srbima."

Dr. Jelić Branimir nastojava da uzme u svoje ruke vođstvo Domobranskog poreta u S.A.D. Severno američko vođstvo Domobranaca sa nepoverenjem gleda 
ovu Jelićevu akciju. Jelić prikazuje sebe kao izaslanika Nemačke, a dr. Pavelića pretstavlja kao zatočenika Italije. Jelić tvrdi, da će Hrvatsku osloboditi jedino Hitler, dok se od Musolinija ne može očekivati nikakva pomoć. Najverovatnije je, da dr. Jelić ovako govori zato, jer se sumnja da Domobranski pokret u Evropi Nemačka finansiski podupire preko Mađarske. Jelić, prema jednom saznanju, raspolaže velikim novčanim svotama i namerava da otpočne sa radio propagandom $\mathrm{i}$ to najpre preko radio stanice u Pitcburgu.

Od strane naših nadležnih faktora preduzeto je potrebno da se ovoj propagandi stane na put.

Dr. Jelić obilazi naše naseobine po Severnoj Americi i propagira za domobransku stvar. Od strane naših zvaničnih organa dobiven je izveštaj, da mu je bio osujećen zbor koji je nameravao održati početkom meseca maja t.g. u Čikagu. Zbor su osujetili Jelićevi protivnici- pristalice g. dr. Mačeka i jugoslovenski orientisani Hrvati, koji nisu dopustili da se crkvene prostorije u kojima je se imao održati zbor upotrebe za ovu propagandu.

Ima se obaveštenje, da je Američka jugoslovenska legija namerna, da preko državnog tužioca u Čikagu preduzme korake da se spreči delje agitovanje dr. Jelića. Istu će nameru preduzeti preko crkvenih vlasti i protivu župnika Čuturića u Čikagu, koji je dr. Jeliću stavio na raspoloženje crkvenu salu.

Ima se obaveštenje, da je dr. Jelić primljen za člana „Hrvatske bratske zajednice"- ogranak Pitcburg, i da sada radi u tesnoj saradnji sa pretsednikom pomenute zajednice Butkovićem. „Hrvatska bratska zajednica“ sa sedištem u Pitcburgu najveća je naša potporna organizacija- sa kapitalom od više miliona dolara; ima i sopstveni list „Zajedničar“.

Dr. Jelić Branimir na svome agitacionom putu po S.A.D.održao je na dan 21 maja t.g. zbor u Pitcburgu u hrvatskoj dvorani ,Javor“. Ovaj zbor na kome su većinom prisustvovali Hrvati i vrlo mali broj Srba, doživeo je potpuni neuspeh. Za ovakav neuspeh Jelić baca krivicu na Srbe i na komuniste.

U stvari baš prisutni Hrvati nisu hteli da dozvole ovom stranom plaćeniku da zavodi mase.

Ovim povodom „Amerikanski Srbobran“ (koji izlazi u Pitcburgu) u svome broju od 23 maja t.g. doneo je članak pod naslovom: „BU-u-u-u!! Više se neće govoriti: Proveo se kao Janko na Kosovu, već: Proveo se kao Jelić u Pitcburgu.“

Na zboru je prisustvovalo, u samoj sali oko 600 osoba, a napolju, pred salom još oko 500 osoba. Čim je spomenuto ime Jelić, nastalo je komešanje i protestvovanje sa uzvicima: „Napolje Jelić, izbacite ga!“‘. Policija je morala da interveniše, no i pokraj njenog pokušaja od skoro puna dva časa da masu umiri, ipak joj to nije pošlo za rukom, tako da je na kraju krajeva dr. Jelić morao da napusti dvoranu.

U pomenutom članku pri komentarisanju ovog zbora kaže se, da je ceo zbor bio sastavljen od Hrvata, koji su dokazali da su svesni istorisko-nacionanog zadatka i da su dali „dostojnu“ nagradu tuđim slugama. 
Ima se izveštaj, da su hrvatski Domobranci iz Amerike uputili Regentu Hortiju memorandum, u kome traže pomoć za ostvarenje njihovih ciljeva. Ovaj memorandum predala je naročita delegacija mađarskom poslaniku u Vašingtonu.

Memorandum sadrži 16 strana a potpisan je od strane 32 člana Hrvatskog narodnog pretstavništva za nezavisnost Hrvatske. Memorandum je štampan u Pitcburgu pod 25 majem 1939 godine.

Prema izvesnim obaveštenjima saznaje se, da su istovetni memorandumi predati i drugim šefovima država.

U našim emigrantskim krugovima u Mađarskoj, ovaj je memorandum učinio vrlo jak utisak; smatra se, da isti pretstavlja početak jedne akcije koja je vrlo jaka, a kojom rukovodi Jelić dr. Branimir.

Postoji obaveštenje, da su hrvatski emigranti u Mađarskoj izvešteni iz Amerike o pripremanju velike akcije protivu naše države. Ovu akciju trebao bi da vodi dr. Jelić, a centar iste za Evropu bio bi u Budimpešti.

Naši emigranti u Mađarskoj veruju da će ova akcija biti ozbiljna. Nije još sigurno, da li će ista biti politička ili teroristička, ali u koliko bi bila teroristička bila bi uperena samo protivu važnijih hrvatskih političara.

Mnogi znaci ukazuju da je odlučeno da se vođstvo ustaškog pokreta skoncentriše u Americi.

Početkom meseca juna t.g. u Americi je proneta nepotvrđena vest, da će dr. Artuković Andrija iz Berlina doputovati u Južnu Ameriku- neznano u koju oblast.

Iz Južne Amerike pak doći će u Severnu Ameriku Anton Valenta, koji sada ima argentinski pasoš, i neki Salković Flajtman, sa ciljem da pomognu dr. Jeliću u njegovoj akciji. Skrenuta je pažnja američkim vlastima na dolazak Valente, koji je 1935 godine bio primoran da napusti S.A.D. zbog njegove po nas štetne aktivnosti među našim iseljenicima u Americi. Isto tako skrenuta je pažnja i na eventualan dolazak dr. Artukovića.

Prema ovom istom izveštaju se sugerira, da akciju ustaša u Evropi predvodi sada Perčević- sa sedištem u Beču. On je potčinjen Jeliću dr. Branimiru, dok su pak njemu potčinjeni svi u Evropi. Dalje se kaže, da je dr. Budak Mile u ulozi vođe ustaša u Jugoslaviji otpočeo sa dopisivanjem sa Amerikom. Nepoznatim kanalima on svoju poštu prebacuje u Mađarsku i Italiju, odakle se dostavlja dalje za Ameriku.

Poznati hrvatski separatista Rudolf Kralj otputovao je na dan 19 maja t.g. iz Buenos Airesa za Trst italijanskim brodom „Neptunija“. Imenovani putuje sa ženom; ima argentinsku putnu ispravu.

Raspolaže se sigurnim obaveštenjem da je Lorković dr. Mladen na dan 19 maja t.g. otputovao iz Budimpešte preko Bratislave u Beč. Ovo se nagoveštava zato, jer se zna da se prepiska Domobranaca iz Amerike za Evropu u glavnom vrši preko Lorkovića. 
2) Rad Hrvatskog komiteta u Italiji

Od meseca februara t.g. povratilo je se kućama: 5 februara-1 emigrant, 9 februara- 4 emigranta, 6 marta- 2 emigranta, 22 marta- 1 emigrant, 5 aprila- 2 emigranta, 13 aprila- 1 emigrant, 22 maja- 2 emigranta, 1 juna- 1 emigrant, 21 juna - 1 emigrant i 22 juna- 2 emigranta.

Od ovih emigranata dvojica su upućeni u Mađarsku: 5 februara Narcis Jasenski i 22 marta Rokuš Stjepan, koji je također mađarski podanik i čija je cela porodica ostala u Mađarskoj.

Među vraćenim emigrantima nalaze se od istaknutijih ljudi: katolički sveštenik don Mate Bulić, iz Kraljevice, koji je nervno oboleo i Gabrijel Jovanović, trgovac iz Metkovića, po koga su nedavno otputovali u Italiju njegov brat i narodni poslanik H.S.S. iz Splita Berković dr. Josip.

Među preostalim emigrantima gro čine Bosanci iz okoline Livna i Duvna, veoma otporni i tvrdoglavi, a pritom odviknuti od svakog posla. Zbog toga radije ostaju u Italiji gde dobijaju 250 lira mesečno, čime uspevaju da se prehrane, nego da se vraćaju u zemlju gde opet treba produžiti sa radom. Osim toga, svi oni čekaju da vide kakav će biti ishod sadašnjih pregovora oko srpsko-hrvatskog sporazuma, kao i da se razbistri mutna spoljno-politička situacija čije bi im eventualno komplikovanje omogućilo produženje akcije.

Ukupan broj do sada vraćenih emigranata iznosi: 261 čovek, 3 žene i 5-oro dece.

Broj u Italiji preostalih emigranata sada iznosi:

-na Liparskim ostrvima (u logoru) - 96 ljudi, 1 žena i 3 deteta,

-na Siciliji (Mesinski okrug) - 6 ljudi,

-na Sardiniji - 87 ljudi,

-u Italiji (kopno) - 43 čoveka, 7 žena i 9 dece.

Svega: 232 čoveka, 8 žena i 12 dece.

Kao što se vidi znatno je povećan broj emigranata na Sardiniji.

Vesti o dr. Artukovićevoj poseti dr. Paveliću, kao i o dr. Pavelićevom odlasku u Berlin i Trst- ne tačne su.

Među emigrantima koji bi želeo da se vrati u zemlju, nalazi se Šime Klanac, iz Posedarja, srez Benkovac. Imenovani je vojni begunac, pobegao je iz artiljerijskog puka u Tuzli, gde je služio svoj kadrovski rok i sada se nalazi interniran u Materi.

Oko polovine meseca juna t.g. imenovani je ponovo izrazio želju za povratak preko narodnog poslanika dr. Berkovića, pod uslovom, da za učinjeno bekstvo iz vojske ne bude kažnjen.

Glavni đeneralštab je obavešten, da je jedna od adresa, kojom se služi Šef ustaške organizacije Pavelić dr. Ante sledeća: Signor Viktorio Ancelotti, Vila Vitori Sezione E.N. 92-III Ventena, Siena. 
3) Rad Hrvatskog komiteta u Mađarskoj.

Nema se nikakvih posebnih konkretnih podataka o radu i aktivnosti ovog komiteta u Mađarskoj. Podaci koji su u vezi sa ovim komitetom izneti su pod „Rad Hrvatskog komiteta u Americi“.

4) Rad Hrvatskog komiteta u Jugoslaviji

Podatak o postojanju Pavelićevih terorističkih organizacija - (osim Sarajeva i Zagreba) - i u drugim banovinama, tačan je, jer je grupa ljudi koji su u Splitu otpočeli izvesan rad u ovom smislu evidentirana od strane policije već od pre izvesnog vremena i stavljena je pod kontrolu i nadzor.

Ova grupa ljudi otpočela je i sa organizovanjem ćelija u ostalim mestima Primorske banovine, u prvom redu u Ljubuškom i Imotskom, gde su već bila izdata i konkretna uputstva za vršenje atentata i terorističkih dela.

Vođstvo ove organizacije, protivu koje još nije bilo dovoljno dokaza, sačinjavali su advokat Bulat dr. Edo i inžinjer Bulić, ali je preranim hapšenjem ovog poslednjeg od strane Uprave policije u Zagrebu, stvar suviše rano otkrivena. Posle ovog hapšenja ljudi iz organizacije prestali su sa radom; sada su se pritajili i nalaze se u očekivanju.

Prema izvesnim podacima, terorističke organizacije Pavelićevaca imale bi otpočeti sa energičnim radom i dejstvom odmah po utanačenju modaliteta Srpskohrvatskog sporazuma, što bi trebalo da nastupi ovih dana. U toku je proveravanja saznanje, da je ova akcija potpomognuta novcem iz Nemačke. Organi bivše H.S.S. stoje u otvorenom neprijateljstvu sa gornjim organizacijama i smatraju ih kao nepodesnim za ostvarenje političkih ciljeva hrvatskog naroda.

Sa više strana iz zemlje i inostranstva dobivena su obaveštenja da ustaška-domobranska teroristička organizacija priprema u najskorijom budućnosti atentate na najviše faktore i visoke ličnosti u našoj zemlji, kako bi se time s jedne strane međunarodnoj javnosti skrenula pažnja na ustašku tezu nezavisne Hrvatske, a sama pak organizacija trgla iz dosadašnje neaktivnosti, a s druge strane, zastrašivanjem, onemogućilo delo sporazuma, čije bi perfektuiranje značilo najveći udar aspiracijama i ciljevima ustaške organizacije.

I same vođe organizacije, posle proučavanja političke situacije u zemlji i inostranstvu, odlučile su se na ovu terorističku akciju kao najefikasniju. Otuda u poslednje vreme, sve veća njihova aktivnost: pojačana je prepiska sa centrima u Evropi i Americi, učestali su sastanci među njima i uspostavljena je veza sa našom zemljom i dr. Pavelićem u Italiji.

Istovremeno se u zemlji oseća pojačana frankovačka akcija, a u Italiji izvesna sloboda dejstva samog „Poglavnika“ dr. Pavelića, za koga je ovih dana otkriveno, da preko izvesnih adresa italijanskih državljana prima korespodenciju od svojih „potčinjenih“, te da će ubuduće on lično putem pisama direktno izdavati naloge za akciju pojedinim centrima. 
S druge strane, postoje nesumnjive indicije koje ukazuju na to, da će ustaškateroristička organizacija i sada najuže sarađivati sa svojim ranijim saveznicima- Makedonskom revolucionarnom unutrašnjom organizacijom (V.M.R.O.) i Kosovskim komitetom, čije su vođe $\mathrm{i}$ istaknutiji članovi takođe raspoređeni po centrima u Evropi i Americi. Pored njih, imaće ovom prilikom i vrlo jake pomagače u našim komunistima, koji su se posle propasti boljševičke Španije nastanili u Francuskoj i koji će, dosledno poslednjim uputima III internacionale iskoristiti do maksimuma u svoje svrhe ovu akciju ustaša.

Sve ove gore iznete činjenice upućuju na to, da se ova nameravana teroristička akcija ima očekivati u najskorije vreme, te sletstveno tome i na to, da joj se ima pokloniti najveća pažnja i da se imaju preduzeti sve mere da se ona u samom začetku onemogući i razvije.

U gornjem cilju potrebno je preduzeti sve potrebne mere, a u prvom redu da obaveštajna služba svih državnih organa u inostranstvu i zemlji, koordinira do maksimuma. Sva saznanja, sva obaveštenja, svi rezultati izviđaja i istrage o akciji ustaških vođa, funkcionera, članova, pokrovitelja, saveznika, prijatelja i simpatizera imaju se najbrižljivije prikupljati i od pomenutih organa međusobno pretresati radi preduzimanja daljih potrebnih mera. Sva lica koja dolaze u obzir za vođenje, rad i pomaganje ustaške terorističke akcije (ustaše, domobranci, frankovci), njihov rad, kretanje, veze, korespodencija i t.d., imaju se podvrći neprekidnom i najstrožijem nadzoru, i o ovome redovno obaveštavati Glavni đeneralštab.

Iako je Glavni đeneralštab sa Pov. Đ. Ob. Br. 8038 od 12-VII-1939 godine izvestio zainteresovane o radu i kretanju pojedinih vođa i istaknutijih članova ustaške organizacije, ipak se ponovo napominje, radi pregleda i lakšeg rada sledeće:

„Poglavnik“ dr, Pavelić Ante, nalazi se konfiniran u Sieni- Italija. Pored njega u Italiji ima još oko 240 ustaša, među kojima i najpoznatiji i najopasniji teroristi organizacije.

Pomoćnik Pavelićev, „Doglavnik“ Budak Mile, nalazi se u Zagrebu gde je pokrenuo svoj list „Hrvatski Narod“. Oko ovog lista okupljaju se povraćeni emigranti, čiji rad, posle povratka, jasno pokazuje da su se vratili po izvesnom unapred određenom planu da bi ustašku akciju organizovali u samoj zemlji. Sa više strana, naročito iz njihove prepiske, utvrđeno je, da je sve to rađeno po nalogu i po odobrenju samog dr. Pavelića.

Sa Budakom sarađuju najviše generalni sekretar ustaške organizacije student Josip Miljković, zatim, Bubalo Ante, advokat, Francetić Juraj i Rajković Marko, studenti, i Potočnik Antun, mehaničar. Pored njih tu se skupljaju i bivši osuđenici- teroristi, pušteni iz kaznenih zavoda, a ostali povratnici, iz drugih mesta, manje-više redovno se javljaju redakciji lista prilikom svog dolaska u Zagreb.

U Nemačkoj, u Berlinu, šef je grupe Riger Vilko, student, na mesto dr. Jelića. Sa njime su braća Gavranović Mijo i Petar, Bukavac Mate i drugi. Gavranovići 
imaju sitničarsku radnju u Beču, i kod njih kupuju svu robu naši pokućarci koji većinom služe za propagatore i kurire ustaške organizacije.

U Beču su stalno, ili samo povremeno navraćaju, Perčević Ivan, potpukovnik i Kodanić Ivan, slikar, pored ostalih manje važnih.

U Gracu je Klobučarić Beno, bivši policiski kapetan, i za njega, kao i za Gavranovića Miju, sumnja se da je u nemačkoj obaveštajnoj službi.

U Budimpešti su dr. Lorković Mladen i Lahovski Emil, a doskoro je bio i dr. Artuković Andrija, koji je pre kratkog vremena otuda nestao i koji će verovatno otići za šefa grupe u Francuskoj.

U Belgiji je Grabovac Nikola, ustaški nadtabornik.

U Americi je Jelić dr. Branimir, koji u društvu sa Antom Došenom, Lukom Grbićem i Antom Valentom, rade svim sretstvima da povrate domobransku organizaciju na nekadašnju zavidnu visinu.

Sva ova lica su u poslednje vreme vrlo aktivna i u stalnom kretanju. Iz njihove prepiske, u koliko se je do sada došlo do iste, vidi se jasno da su se odlučili za terorističku akciju i da ista treba da otpočne što pre.

Što se tiče njihovih saveznika, poznato je da se Ivan Mihailov, šef organizacije V.M.R.O. nalazi u Poljskoj i da su sa njime, njegova desna ruka Čkatrov Jordan, kapetan Brdarov (jedan od najviđenijih među teroristima), Georgijev iz Varne, -isto kao i Brdarov- kao i drugi, koji se, kao i neki članovi Kosovskog komiteta šetaju po Evropi, sastaju i dogovaraju jedni s drugima, sve u cilju obnavljanja zajedničke akcije protivu naše zemlje.

Izvesne indicije pak, ukazuju i na to da ima država koje ili toleriraju ili sa blagonaklonošću gledaju na ovu akciju, kako bi mogle u danom trenutku istu iskoristiti za svoje ciljeve. Zbog ove blagonaklonosti, značaj ove akcije je mnogo veći, te otuda i veća potreba za sve naše pozvane državne organe da ostavljajući nastranu, u opštem interesu, sve ostale momente koji bi tome smetali, ulože sve svoje sile i znanje u jednu zajedničku i koordiniranu akciju da se rad naših neprijatelja onemogući.

Glavni đeneralštab moli, da mu se povodom ovoga dostave i eventualne sugestije u cilju uspešnije borbe, a isto tako da bude obavešten o svima eventualnim smetnjama lične i druge prirode koje bi ovaj rad mogle ometati, te kako bi se iste mogle otkloniti.

KRAJ

Dokument $6^{8}$

Tromjesečni izvještaj aktivnosti Makedonskog, Kosovskog i Hrvatskog komiteta za travanj, svibanj i lipanj 1940. godine. ${ }^{9}$

$8 \quad$ INI, Skopje, Dokumentaciono oddelenie, KXXXVI/7 Br. 736

9 Za ovaj dokument ne posjedujem prvu stranicu izvještaja pa ne znam tko je i kome to slao. Da se radi o izvještaju za ta tri mjeseca, zaključujem po knjizi navedenoj u bilj. 1. 


\section{HRVATSKI KOMITET}

1) Rad Hrvatskog komiteta u Americi.

Ustaše u Americi nisu uspeli da uspostave direktnu vezu sa Pavelićem, te mu pišu na Bolonju, odakle se prepiska vraća. Zaključak: ustaši su se koncentrisali po drugim mestima.

Ustaško starešinstvo u Severnoj Americi uputilo je, po nalogu Pavelića, preko italijanske i nemačke ambasade u Sjedinjenim Američkim državama, apel Čanu i Hitleru, da se na idućoj konferenciji mira zauzmu, da Hrvatska bude proglašena nezavisnom državom. U apelu se oštro osuđuje sporazum od 26. avgusta 1939. i politika g. Dr. Mačeka.

Tamošnji domobranci primili su novu poruku „Poglavnika“, u kojoj se javlja, da Pavelić ima stalne sastanke sa nemačkim i italijanskim emisarima, na kojima pretresa plan o ulasku trupa u Hrvatsku, do čega može doći svakog časa. Dalje se kaže, da još nije rešeno pitanje, koja će vojska tamo ostati, ma da se Pavelić nada, da će Nemci i Italijani pristati da to bude Hrvatska vojska.

Zatim Pavelić izražava žaljenje, što se nije javljao neko vreme. Razlog tome je, što je bio upozoren, da je cela njegova korespodencija došla u ruke jugoslovenskih organa. Sad prekida ćutanje, pošto se radi o eminentnoj akciji. Engleske vlasti odlučile su da Dr. Branimira Jelića zadrže u pritvoru do kraja rata.

2) Rad Hrvatskog komiteta u Italiji.

U poslednje vreme u nekim stranim državama opaža se ustaška delatnost, koju vodi poznati Dr. Ante Pavelić. On je stupio u vezu sa stranim neprijateljskim emisarima, koji su neprijateljski raspoloženi prema našoj državi.

Verovatno je da će se pod vođstvom Pavelića ponova organizovati ustaška akcija i upadi u našu državu. Po istom obaveštenju isto tako je tajno obnovljen takozvani Crnogorski komitet.

Ustaška kacija (akcija - op. priređivača) u Italiji pokazuje u poslednje vreme veću aktivnost. Ustaške vođe došle su u vezu sa zvaničnim italijanskim organima. U vezi gornjeg potvrđeno je proverom sledeće:

Pavelić je 12. maja zajedno sa ženom, a u pratnji Konti-a, otputovao u pravcu Florencije, gde je i otseo u ulici Gofredo Mameli broj 42. Čuvaju ga više agenata; stavljen mu je na raspoloženje 1 zatvoren automobil.

U stanu Pavelić prima posete najvažnijih ustaša. Primio je do sada Vjekoslava Servacija, Antona Godinu, njegovu ženu zvanu ,plava dama“, Kvaternika, Tomića Tomu i jednog starijeg čoveka. Servaci treba da bude upućen na granicu, dok bi Godina sa ženom trebao da ode u okolinu Rijeke ili Trsta. Drugi emigranti su na svojim mestima da se ne bi izazvala naša sumnja. Sa ostalim viđenijim emigrantima uspostavljali su vezu porukama ili preko pisama.

U Florenciji je Pavelić primio pomoćnika Načelnika Političkog odelenja Ministarstva inostranih poslova grofa Vida, koji ima za referisanje i hrvatsku emigraciju. 
Preko Šimića Marijana na Sušaku išla je veza sa Pavelićem. Preko neke žene Milke Grzeks post restant na Rijeci dostavlja se pošta. Preko generalnog konzulata u Zagrebu upućen je novac za akciju.

Za Godinu se zna, da se u poslednje vreme često pojavljuje u Trstu, gde se bavi trgovinom ribe. Otseda sa nekom Antonijetom u via Zara br. 12.

Pouzdano je utvrđeno da je 29 maja 1940 boravio u Opatiji (Abacija) emisar Dr. Ante Pavelića Servaci. Imenovani je preko Popova Dušana, đaka gimnazije na Sušaku, uputio poziv na sastanak u Opatiji sledećim licima iz Sušaka:

Dr. Ljubinu Josipu, lekaru okružnog ureda na Sušaku i honorarnom garnizonom lekaru; Šimiću I. Marijanu, veletrgovcu sa Sušaka, i Blažini I. Josipu, župniku sušačke župe.

Na sastanak su otišli Dr. Ljubin i Šimić Marijan, dok je Blažina poručio da se slaže sa politikom Dr. Pavelića, ali da ne želi učestvovati u terorističkim akcijama.

Sastanak je imao cilj organizaciju nereda i sabotaže i formiranje odelenja od frankovaca, klerikalaca i ranijih ustaša, koji još simpatišu akciju Italijana, da bi se na taj način pružila pomoć eventualnoj akciji Italije sa mora i iz vazduha.

Vrlo je verovatno da je tome sastanku prisustvovao veći broj pristalica Pavelićevih, do kojih se detalja još nije došlo.

Posle ovoga sastanka nestao je sa svojom porodicom Šimić Marijan sa Sušaka. Ukoliko je do sada utvrđeno, ostao je u Opatiji. Pored Šimića nestao je Došen G. Pavao, gostioničar, koji je služio kao kurir između ustaša u Italiji i onih u Zagrebu, Senju itd.

Prebacivanje u Italiju pristalica Ante Pavelića iz Zagreba ubuduće treba da se vrši preko Gospića i Barić Drage na moru. Dok se ne uluči prilika za prelazak, oni će se skrivati u ovome mestu kod trgovca Marka Pavičića, pošto je tu, prema istom saopštenju, nedovoljna kontrola naših vlasti nad barkama koje odlaze u Zadar.

Pristalice Pavelića (bivše ustaše), koji se sada nalaze u Italiji, kao i dalmatinski renegati, na slučaj ratnog zapleta između naše države i Italije, imali bi se upotrebiti za akciju protivu nas.

U tom cilju pristalice Pavelića se vežbaju na pojedinim italijanskim aerodromima kao vazdušna pešadija za vazdušne desante oko sela i predela na našoj teritoriji, gde imaju svojih pristalica. Izveštaj je u toku proveravanja.

Prema jednom neproverenom izveštaju saznaje se, da je iz Varšave Ivan Mihailov došao u Italiju, gde je u Florenciji imao sastanak sa Pavelićem. Baš ovih dana izgleda, da se Mihailov nalazi u Arbaniji radi stupanja u vezu sa Kosovarima i da prikuplja ljude i stvara kanale za predstojeću akciju u slučaju da nas Italija napadne.

Pavelić se već dopisuje sa nekima u Arbaniji.

U Italiji se nalaze mnogi Makedonci, koji su izgleda kao radnici prebačeni u Arbaniju.

Generalnom inspektoru kancelarije za nadzor nad emigrantima, dr. Kontiju napomenuto je, da Mihailov ništa više ne znači, pa čak ni kao terorista, jer ga ni u ranijoj njegovoj bandi niko ne priznaje. 
Veruje se da će italijanske vlasti Mihailovu i hrvatskim emigrantima za sada onemogućiti ma kakve incidente, ali da će se sa ovima i dalje sporazumevati i dozvoliti im organizovan rad.

Prema jednom pouzdanom izveštaju, u Milanu je održan sastanak između članova Gestapo-a i Ovra. Na ovom sastanku prisustvovali su i emigranti iz Jugoslavije.

Grupa ovih agenata krenula je iz Milana prema Trstu, kako bi se u pogodnom momentu prebacili u našu državu.

U poslednje vreme u Italiji su rado primljeni svi emigranti i ekstremistički elementi iz Jugoslavije, koji se vraćaju iz zemalja koje su sada u ratu (Belgije, Holandije, pa i Švajcarske).

3) Rad Hrvatskog komiteta u Mađarskoj.

Prema podacima od 20 maja 1940 u Mađarskoj je otpočelo organizovanje svih makedonstvujuščih- pripadnika V.M.R.O. Neki major Mandalijev, rodom iz Ohrida nalazi se tamo u tom cilju. Hrvatski emigranti, koji su poslali u Mađarsku jednog svog pretstavnika iz Beča, sarađuju u pomenutoj organizaciji rada.

Iz prepiske Dr. Andrije Artukovića iz Budimpešte vidi se, da Artuković ima za dužnost, da spremi u Budimpešti lažne putne isprave za ustaše, koji bi se imali da upute u našu zemlju pre početka akcije. Ovu akciju ustaška organizacija namerava da pokrene i kao deo akcije jedne strane sile.

4) Rad Hrvatskog komiteta u Jugoslaviji.

U vezi sa akcijom Dr. Pavelića i njegovih agenata u Opatiji saznaje se, da je preduzeta neka akcija oko prikupljanja potpisa za neku pretstavku.

Od naših sunarodnika na Rijeci i ličnosti koje prelaze na Rijeku Šimić Marijan i njegovi saradnici traže potpis za jednu peticiju.

Govori se da se i u unutrašnjosti Hrvatske banovine prikupljaju ti potpisi od strane agenata hrvatskih nacionalista (fašista).

Cilj prikupljanja ovih potpisa tumači se dvojako: Jedna verzija ukazuje na to, da se želi spremiti peticija silama osovine za slobodnu Hrvatsku pod protektoratom jedne od osovinskih sila.

Druga verzija ukazuje, da je cilj ove akcije postići izvesne promene u banovini Hrvatskoj i izvesna prava nacionalistima.

U ustaškom vođstvu u Zagrebu rešeno je, da se emigriranje Pavelićevih pristalica u Italiju ne vrši više preko Sušaka, nego preko Gospića i Barić Drage (blizu Krušćice) koja leži na moru ispod Velebita i gde pristaju putnički brodovi. U Barić Dragi ovi bi se skrivali kod trgovca Marka Pavičića do polaska za Zadar.

Mimo Vukić, sopstvenik motornog jedrenjaka iz Kruščice, treba da je ovih dana uhvaćen u krijumčarenju oružja i stražarno sproveden u Zagreb.

Jerolim Katić, sopstvenik novootvorene gostionice „Stari grad“ u Petrinjskoj ul. u Zagrebu prodao je istu za 25. 000 dinara iz razloga što se ustaši nisu mogli 
ovde više skupljati. On se sada nastanio kod ženinog brata u Daničićevoj ul. br. 28 u Zagrebu.

U Zadru se ustaši sastaju kod Ivana Vukića, našeg podanika nastanjenog onde još od pre prošlog rata, koji sada drži gostionicu, kao i kod Mate Bakaša, koji ima prodavnicu duvana u blizini suda u Zadru, rodom iz Šibenika, koji je tamo prebegao 1919.

Novi list „Hrvatska gruda“, koji izdaju Pavelićeve pristalice u Zagrebu, stiže na Sušak poštom određenim pretplatnicima i ne može se dobiti u slobodnoj prodaji.

Milka Grzeks iz Sušaka, činovnica u radnji trgovca Marjana Šimića održava i dalje veze sa svojim gazdom, koji se sada nastanio u Opatiji u vili „August“. Od njega je nedavno dobila nalog da vrbuje što veći broj Pavelićevih prijatelja, koji bi prebegli u Italiju. Na taj način pozvala je nekog Jure Klaneca iz Posedarja (ispod Velebita) da pređe u Italiju, ali je ovaj odbio da to učini.

Po svemu izgleda da Pavelić reorganizuje svoje ustaše, prema iskustvima na zapadu Evrope t.j. po svemu izgleda da svoje pristalice organizuje kao italijanske padobrance.

Kraj 
Confidential reports of the Intelligence unit of the Royal Yugoslav Army's General Staff on Ustasha migration (Croatian Committee)

\section{7 - 1940: Documents}

In the years before the outbreak of the Second World War, the state authorities of the Kingdom of Yugoslavia monitored the activities of various separatist organizations that were dissatisfied with the position of their nations in the Kingdom. The General Staff (Glavni đeneralstab), through its intelligence unit, monitored Macedonian, Albanian and Croatian émigrés and reported on their actions on a quarterly basis. Copies of these reports have been stored for several decades at the Institute of National History in Skopje. Documents relating to the Kosovo Committee were published in the bilingual (Albanian-Macedonian) edition of the State Archive of the Republic of Macedonia (Državen Arhiv na Republika Makedonija). Thanks to Muzafer Bislimi, editor of that edition, copies of documents relating to the Croatian Committee (Ustasha Organization) will be presented to the Croatian public in this article. The text in Cyrillic script was transliterated into Latin script, but the text was transcribed in the original - in the Serbian language with all the language inaccuracies contained therein. I was in the possession of only those parts of the text that relate to the Croatian Committee, but by using the Macedonian edition I could, in most cases, determine when and who wrote the reports and for whom they were intended.

Keywords: Croatian Committee, Ustasha, Kingdom of Yugoslavia Army General Staff, Intelligence unit.

Ključne riječi: Hrvatski komitet, ustaše, Glavni generalštab vojske Kraljevine Jugoslavije, obavještajni odjel.

Igor Despot

OŠ Savski Gaj Remetinečka cesta 64a, HR-10000 Zagreb idespot@net.amis.hr 


\section{FILOZOFSKI FAKULTET SVEUČILIŠTA U ZAGREBU \\ ZAVOD ZA HRVATSKU POVIJEST \\ INSTITUTE OF CROATIAN HISTORY \\ INSTITUT FÜR KROATISCHE GESCHICHTE}

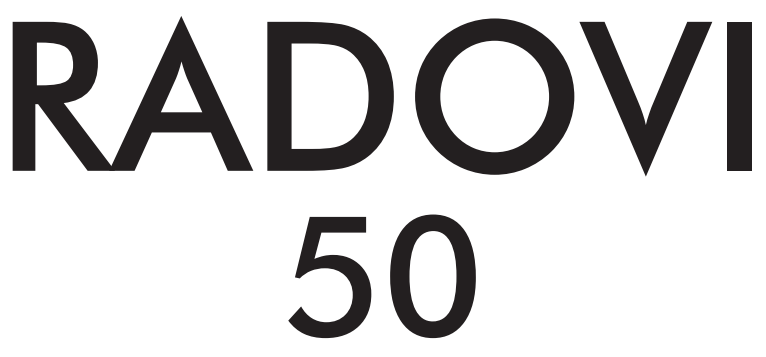

BROJ 2

ZAVOD ZA HRVATSKU POVIJEST

FILOZOFSKOGA FAKULTETA SVEUČILIŠTA U ZAGREBU

\section{FF press}

ZAGREB 2018. 


\title{
RADOVI ZAVODA ZA HRVATSKU POVIJEST FILOZOFSKOGA FAKULTETA SVEUČILIŠTA U ZAGREBU
}

\author{
Knjiga 50, broj 2
}

\author{
Izdavač / Publisher \\ Zavod za hrvatsku povijest \\ Filozofskoga fakulteta Sveučilišta u Zagrebu \\ FF-press \\ Za izdavača / For Publisher \\ Vesna Vlahović Štetić \\ Glavni urednik / Editor-in-Chief \\ Hrvoje Gračanin \\ Izvršni urednik / Executive Editor \\ Nikola Anušić \\ Uredništvo / Editorial Board
}

Bruna Kuntić-Makvić (stara povijest/ancient history), Zrinka Nikolić Jakus (srednji vijek/

medieval history), Hrvoje Petrić (rani novi vijek/early modern history), Željko Holjevac (moderna povijest/modern history), Tvrtko Jakovina (suvremena povijest/contemporary history),

Silvija Pisk (mikrohistorija i zavičajna povijest/microhistory and local history),

Zrinka Blažević (teorija i metodologija povijesti/theory and methodology of history)

Međunarodno uredničko vijeće / International Editorial Council

Denis Alimov (Sankt Peterburg), Živko Andrijašević (Nikšić), Csaba Békés (Budapest), Rajko Bratož (Ljubljana), Snježana Buzov (Columbus, Ohio), Svetlozar Eldarov (Sofija), Toni Filiposki

(Skopje), Aleksandar Fotić (Beograd), Vladan Gavrilović (Novi Sad), Alojz Ivanišević (Wien),

Egidio Ivetić (Padova), Husnija Kamberović (Sarajevo), Karl Kaser (Graz),

Irina Ognyanova (Sofija), Géza Pálffy (Budapest), Ioan-Aurel Pop (Cluj),

Nade Proeva (Skopje), Alexios Savvides (Kalamata), Vlada Stanković (Beograd),

Ludwig Steindorff (Kiel), Peter Štih (Ljubljana)

Izvršni urednik za tuzemnu i inozemnu razmjenu /

Executive Editor for Publications Exchange

Martin Previšić

Tajnik uredništva / Editorial Board Assistant

Dejan Zadro

Adresa uredništva/Editorial Board address

Zavod za hrvatsku povijest, Filozofski fakultet Zagreb, Ivana Lučića 3, HR-10 000, Zagreb

Tel. ++385 (0)1 6120 150, 6120 158, faks ++385 (0)1 6156879

Časopis izlazi jedanput godišnje / The Journal is published once a year

Časopis je u digitalnom obliku dostupan na / The Journal in digital form is accessible at

Portal znanstvenih časopisa Republike Hrvatske „Hrčak“ http://hrcak.srce.hr/radovi-zhp

Financijska potpora za tisak časopisa / The Journal is published with the support by Ministarstvo znanosti, obrazovanja i športa Republike Hrvatske

Časopis je indeksiran u sljedećim bazama / The Journal is indexed in the following databases: Directory of Open Access Journals, EBSCO, SCOPUS, ERIH PLUS, Emerging Sources Citation Index - Web of Science 


\title{
Naslovna stranica / Title page by
}

Iva Mandić

\section{Grafičko oblikovanje i računalni slog / Graphic design and layout Marko Maraković}

\author{
Lektura / Language editors \\ Samanta Paronić (hrvatski / Croatian) \\ Dražen Nemet (engleski / English)
}

Tisak / Printed by

Tiskara Zelina, Sv. Ivan Zelina

Naklada / Issued

200 primjeraka / 200 copies

Časopis je u digitalnom obliku dostupan na Portalu znanstvenih časopisa Republike Hrvatske „Hrčak“ http://hrcak.srce.hr/radovi-zhp

The Journal is accessible in digital form at the Hrcak - Portal of scientific journals of Croatia http://hrcak.srce.hr/radovi-zhp 